\title{
WHAT ARE RECENT DEVELLOPMENTS IN COLLEGE-ADMISSION POLICIES?
}

Chairman: F. M. Peterson, Superintendent of the Community High School, Pekin, Illinois; Chairman, Committee on School and College Relations, NASSP

Discussants:

Dana M. Cotton, Director of Placement, Graduate School of Education, Harvard University, Cambridge, Massachusetts

Harold Gray, Principal, Clover Park High School, Tacoma, Washington

Summary of the presentation made by OLIVER W. MELCHIOR

I

N OUR day we have witnessed an unexampled burgeoning of demand for secondary education. We have already survived the first thrust of increased demand for higher education. A more staggering assault for admission to college lies immediately ahead. In such an era college admission policies have had to be overhauled and modified. They will have to be modified further and new techniques will have to be developed.

Some of the questions which are being raised concern the following: uniform school record blank, reliable indices of academic ability and promise, agencies for communication, selective admission, expansion of facilities, financial need, advanced standing and credit, and the importance of the individual in an era of expansion.

\section{UNIFORM TRANSCRIPTS}

The school record still remains as the most important single criterion for admission. The volume of these transcripts poses an increasing problem for schools and colleges. Standardization of this page of the college application is one of the logical steps which must take place. The SchoolCollege Relations Committee of the NASSP is working jointly with a comparable committee of the American Association of Collegiate Registrars and Admissions Officers to revise the NASSP Secondary-School Record form to make it even more widely acceptable.

Standardization of the method of computing class rank has received much attention and is to be hoped for. With the mobility of our population and especially that portion of it which is college bound, a common coinage becomes almost indispensable. While we glory in the advantages of decentralization of our educational structure and while we cherish our diversities, must we not agree on a common means of communicating the most essential data?

Oliver W. Melchior is Principal of the Scarsdale High School in Scarsdale, New York. 


\section{Scholastic AptrTude}

Increasing interest in reliable indices of ability to do school and college work is developing rapidly in some parts of the country, while other sections have had a generation of experience with such tests. The greatest danger lies in the misuse of such scores, but we shall have much more attention given to state-wide, sectional, and national testing programs to measure academic ability as well as achievement.

\section{Agencies for CoMmunication}

The Joint School-College Relations Committee of the NASSP and the American Association of College Registrars and Admission Officers is serving as one example of the endeavor to exchange ideas and to share problems. In addition to secondary school-record revision, this group is working on questions of pre-college guidance including a code of ethics for College Days, testing programs, advanced standing and credit, class rank, scholarship programs, multiple applications, and the like. They would appreciate your suggestions for further items for study.

Sectional and state groups as well as other organizations of national scope form the avenues through which the newer ideas must be implemented. The annual Colloquiums of the College Entrance Examination Board, such an organization as the Admissions Counselors of American Colleges, and numerous others are serving ably in diagnosing the problems and seeking solutions.

\section{Selective Admission}

Those institutions which have been practicing selection before admission are faced with the question of whether to continue to select on the basis of class rank and test scores primarily or whether to endeavor to admit a representative class. This leads to severe problems of public relations when candidates of superior qualifications are rejected. Institutions which have admitted all candidates who meet the test of certification will have to expand their facilities enormously or practice selective admission. The former institutions have reduced freshman failure to less than five per cent in some cases. In the latter colleges where selection actually takes place during the freshman year, resulting in freshman failure as high as fifty per cent, the problem of waste of time as well as resources is a perplexing one.

\section{EXPANSION of Facilities}

The American pattern is to meet the demand. This will be no less true in education, belatedly in many cases and at a sacrifice of luxuries, but the need will be met. It is heartening to read of the plans for a Dearborn campus of the University of Michigan. New York State has just announced plans for the establishment of ten new junior colleges. There are other examples and there will be more. 


\section{Financial NeEd}

Scholarship aid will have to be expanded greatly. Private philanthropies are doing what they can and our great corporations are playing a new role in this field. The National Scholarships are indicative. We will have to be sure that the recipients in our schools appreciate the value of such aid and do not come to expect such assistance as a right rather than a privilege.

\section{Advanced Standing and Credit}

Increasing attention will be given to providing challenges to our most gifted pupils. Early admission, advanced courses in high school leading to advanced standing and even advanced credit in college, enrollment of high-school seniors in part-time college courses on nearby college campuses are some of the devices which are in use. We must find the means to provide the gifted with opportunities that match their abilities. Education for all does not mean that all must have the same education.

\section{IMPORTANCE OF THE INDIVIDUAL}

As we face the problems of readjustment, we must avoid the pitfalls of mass education. Individuality has made America strong, and there must be scope for the individual to develop as he should. The new dimension to be added to the criteria for admission to college will almost certainly be to find a way to measure or forecast the motivation of the candidate. At present this is approached on a subjective basis only. Whether an objective method can be found is in dispute. At any rate, one of our prime responsibilities is to provide an education in which the student sees purpose and design and in which he can find an allegiance to learning for its own sake.

\section{Summary of the presentation made by CLYDE VROMAN}

ERTAIN conditions in our country are causing important changes in college admission policies. Our college-age population is expanding rapidly; an increasing proportion of high-school graduates are going to college; the search for our more able youth, supported by corporate scholarship funds, is bringing increased numbers of these better students to colleges; and students are staying in college longer for advanced education. As a result, colleges are being deluged with applications for admission, and we can expect the demand for a college education at least to double in the next decade.

Clyde Vroman is Director of Admissions at the University of Michigan in Ann Arbor, Michigan; and Chairman of the Committee on High School-College Relations, American Association of Collegiate Registrars and Admissions Officers. 


\section{College Facilities}

The alarming fact in American higher education is that we are not expanding our colleges and universities commensurate with the needs of our college-age population. Most independent or private colleges are either forced through lack of funds to remain at their present sizes or have chosen not to expand. This means that these independent institutions will provide a continually smaller proportion of the college education for American youth. Public or tax-supported colleges and universities are expanding considerably, but it is still a question whether adequate higher education facilities will be made available in each state. In some states there is talk about "exporting" more of their students to colleges in other states, while most of these other states are faced with the problem of reducing the proportion of out-of-state students to be admitted. This lack of college facilities is already causing changes in the admission policies and practices of many colleges and universities which are of vital importance to secondary schools.

\section{Trends In College Admissions}

The first and most obvious trend is that colleges are becoming more selective in their admissions. The college with a defined size of freshman class to be admitted finds itself with a larger number of applications and so it simply takes the best qualified students. The effect is higher admission standards. The public institutions vary in their practices. Some admit all high-school graduates, but a fair proportion of state supported colleges and universities have always had selective admissions and now are increasing their admission standards. The striking trend in most states is toward a variety of different kinds of colleges ranging from community colleges to universities, with each type of institution serving a unique role in the system of higher education. This is a wholesome trend. With such adequate facilities, principals can send their graduates to colleges which in terms of offerings and academic competition will be reasonable for "each student. "Selective admissions" then may become truly "guided admissions."

A second very important trend is the increased use of standardized examinations, such as those of the College Entrance Examination Board, as a part of the admission process. More independent colleges and universities are now requiring the College Board tests as a condition of admission. Some state universities are requiring the College Board tests of outof-state applicants, because these universities are receiving applications from more qualified students than they can admit and must find new ways to identify the best students. The use of the College Board tests in certain prominent national scholarship programs has increased the number of students taking the College Entrance Examination Board tests each year. Probably every high school which sends its graduates to colleges outside of its immediate area has students taking the College Board 
examinations. These examinations are good and hold many possibilities for constructive guidance of college-going youth. It is crucial that every principal and his counselors be informed and skillful in the use of the results of the College Board tests, for they will play an increasing role in the transition from school to college in the decade ahead.

A third trend in college admission is toward the selection of students so as to insure such characteristics as geographic spread, variety of interests and achievements, and other qualities desired by the particular college.

Then, too, there are other trends such as increased use of interviews, more emphasis on academic preparation, more financial aid for worthy students, application fees, and requests for more personal information about applicants.

\section{RECOMMENDATIONS}

In the difficult decade ahead, it will be helpful if each high school will prepare a descriptive, factual statement about itself-the high school, the community, and the nature of the senior class, such as the intelligence level of the class, the numbers of graduates usually entering colleges, which colleges they entered, and how they succeeded in these colleges. In addition a duplicated one-page summary of the nature, strengths, weaknesses, and interests of each senior could be prepared to accompany his applications for admission to colleges. And finally, when a student applies to a college, the school, in addition to providing copies of the two statements above, should analyze and make recommendations about his readiness for the college to which he is applying. Principals who do these things will have better success in placing their graduates in preferred colleges.

Colleges likewise have a responsibility. Each college should furnish each applicant and his high school a statement of the nature and ability level of its typical freshman class, its admission standards, policies, and practices, and other information needed by the applicant.

With such information as suggested above, we can hope to have guided admission implemented by cooperation between secondary schools and colleges and executed with all possible fairness to students and their families.

\section{In Conclusion}

The significance of the trends described above is that we must act quickly. It is not too late to take positive action toward the solution of our mutual problems. If we fail to take constructive action, we soon will find ourselves in real difficulty. 